Márkus, Éva and Maya Lo Bello. "Mihály Lieb or Mihály Munkácsy? Developing Cultural Identity in Hungary’s German National Minority Schools." Hungarian Cultural Studies. e-Journal of the American Hungarian Educators Association, Volume 14 (2021): http://ahea.pitt.edu DOI: 10.5195/ahea.2021.426

\title{
Mihály Lieb or Mihály Munkácsy? Developing Cultural Identity in Hungary's German National Minority Schools
}

\author{
Éva Márkus ${ }^{1}$ and Maya Lo Bello ${ }^{2}$
}

\begin{abstract}
In the Carpathian Basin, German-speaking peoples have lived alongside Hungarians for hundreds of years, resulting in many, shared points of cultural intermingling. (Although commonly referred to as svábok ['Swabians'], this is not the correct term for Hungary's German minorities since their origins differ from those of Swabians living in Germany today). After World War II, thousands of Hungarian Germans were deported to Germany. Those who remained could not use their native language and dialect in public. Today, young generations reconnect with their German roots in statefunded, national minority schools where, through the medium of Hochdeutsch, students are familiarized with their Hungarian German dialect, history and traditions in a subject called népismeret ['folk education']. Since families cannot always provide a sense of Hungarian German identity, teachers have to enrich their students' connection while deepening their awareness of the many ways in which ethnic Germans have contributed to Hungarian history and culture. This paper provides a brief overview of the current legal documents and rulings that determine the curriculum in Hungary's national minority schools before detailing the topics studied in a Hungarian German folk education class. We contend that the overwhelming losses in cultural heritage that resulted from assimilation must be reversed in a process that simultaneously respects their unique, dual identity. To this end, we recommend adapting the curriculum of folk education to include an alternative, more inclusive perspective of famous, "Hungarian" individuals.
\end{abstract}

Keywords: Hungarian Germans, national minority schools, education in folk traditions, identity, culture, history

Biographies: Dr. Éva Márkus (habil.) is Faculty Dean of Eötvös University's Faculty of Primary and Preschool Education (ELTE TÓK). After completing her degree in Germanic Studies at Eötvös University's Faculty of the Humanities (ELTE BTK), she achieved her PhD in the field of linguistic studies. The title of her dissertation was German Dialects in the Villages of Buda's Hill Regions. Her habilitation thesis focused on Deutschpilsen, the German dialect found in Nagybörzsöny, and was published by Praesens Publishers (Vienna) in 2014. A professor at ELTE TÓK's Department of Foreign Language and Literature, she teaches German-language courses in subjects related to Hungary's German minority groups, including ethnography, history, literature and children's literature,

${ }^{1}$ ORCID: 0000-0002-3571-8472

${ }^{2}$ ORCID: 0000-0003-1571-1123

$($ (c) $)$ EY

ULIS D-Sente
New articles in this journal are licensed under a Creative Commons Attribution 4.0 International License.

This journal is published by the University Library System of the University of Pittsburgh as part of its D-Scribe Digital Publishing Program and is cosponsored by the University of Pittsburgh Press 
Márkus, Éva and Maya Lo Bello. "Mihály Lieb or Mihály Munkácsy? Developing Cultural Identity in Hungary’s German National Minority Schools." Hungarian Cultural Studies. e-Journal of the American Hungarian Educators Association, Volume 14 (2021): http://ahea.pitt.edu DOI: 10.5195/ahea.2021.426

and has published texts in each area. Her research examines Hungarian German dialects and the past and present of national minority education in primary and preschool education. markus.eva@tok.elte.hu

Dr. Maya J. Lo Bello is a professor at ELTE TÓK's Department of Foreign Language and Literature, where she teaches English-language courses and literature. She completed her PhD in Modern Hungarian Language and Literature at ELTE BTK; her research focuses on the role played by assimilation in Miksa Fenyö's career in both the modern literature movement of Nyugat ['West'] and the industrialization of Hungary's economy via his position at the Hungarian Industrialists' Association, GyOSz. Her latest study, Chasing Impressions: A Comparative Cultural Analysis of Impressionistic Criticism in Hungary, was published in 2019 by the University of Pennsylvania's journal, Comparative Literature. Studies. Maya Lo Bello translates extensively and is Technical Editor of the journal, Hungarian Cultural Studies. lo.bello.maya.jean@tok.elte.hu

\section{An Overview of the History of Germans in the Carpathian Basin}

For the past millennium, Germans and Hungarians have coexisted within the Carpathian Basin in a relationship that stretches back to the founding of the Hungarian state. This peaceful and profitable collaboration has guaranteed these German ethnic groups a place in Hungarian history. Already in the tenth century, Gizella, Princess of Bavaria and future wife to the Hungarian Kingdom's first ruler, King Stephen, arrived at the Hungarian court with a retinue of German knights, priests and peasants who were charged with the task of spreading Christianity, reinforcing the centralization of King Stephen's rule and creating an ecclesiastical and secular infrastructure that would establish an administration based upon the Western system of bishoprics and county seats. During Géza II's reign (1141-1162), the settlement of various German groups increased until, by the beginning of the thirteenth century, numerous Saxon communities had formed in Transylvania and the Upper Highlands region of Szepesség [Spiš in Slovakian, Zips in German] located in present-day Slovakia. In response to the Tatar attack launched against his kingdom, Béla III (1172-1196) and his successors progressively established fortified cities that were mainly inhabited by Germans and endowed with rights that had previously been bestowed upon German municipalities. The legal codes contained in the Sachenspiegel [Saxon Mirror, circa 1220-1235] or Schwabenspiegel [Swabian Mirror, circa 1275] codexes also formed an important basis for the continued preservation of German peoples' rights. In fact, the new technologies and skills that Germans brought with them was one reason why Hungary's rulers were not only willing to establish German communities within their territories, but also granted these settlements special privileges. Among others, these settlements included both the separate sites of Buda and Pest as well as significant centers of mining located in Lower and Upper Hungary, where the production of precious metals such as gold and silver or copper contributed to the nation's economic prosperity. While Germans were mainly key in disseminating new skills in the field of agriculture during the early medieval period, later, new mining techniques for extracting gold and silver from lead were brought to Hungary from Germany and Italy, thereby ushering in a boom in the production of ore and metal that made Hungary one of Europe's wealthiest kingdoms.

The laws and rights brought from Germany's municipalities and territories reaped significant socio-economic benefits and changes in Hungary, where their introduction led to the establishment of the constitutional and legal norms necessary for autonomy together with the regulation and overall organization of economic activities within trade guilds. Parallel to the feudal structure of Hungary's agrarian sphere, these medieval cities opened up zones that were free to conduct foreign trade with cities located in Southern Germany, Silesia and Northern Italy, a factor that further fueled Hungary's economic development (Sewann 2013: 85). While the 
Márkus, Éva and Maya Lo Bello. "Mihály Lieb or Mihály Munkácsy? Developing Cultural Identity in Hungary’s German National Minority Schools." Hungarian Cultural Studies. e-Journal of the American Hungarian Educators Association, Volume 14 (2021): http://ahea.pitt.edu DOI: 10.5195/ahea.2021.426

Germans who settled in Hungary during medieval times had to clear uninhabited and uncultivated areas often covered in dense forests, those Germans who arrived in the eighteenth century after the removal of Ottoman forces faced the destruction wreaked by two hundred years of Turkish occupation. Once the Ottomans left Hungary, changes in safety and the economy pushed landholders to switch from pasturing extensive herds to engaging in intensive farming. As a result, the South Slavic peoples who had specialized in animal husbandry were forced from their previous homes and replaced by German peasants who plowed plains left fallow and altered the structure of villages to meet the demands of Dreifelderwirtschaft, a crop rotation system in which fields were divided into thirds for the purpose of nurturing plants that would ensure soil quality. Throughout the eighteenth century, German settlers introduced the rotation of grain crops, the application of manure to fields, the rearing of livestock in stables and the cultivation of newly domesticated plants, such as swedes, cabbage, potato and tobacco. Along with these improvements, they also brought the German concept of inheritance, meaning that ownership of the family's holdings was bestowed upon the eldest son. Younger sons either used whatever monetary share they had received to establish their own farms or chose to become teachers, priests or doctors in a decision that necessitated relocating to an urban center, where opportunities in social mobility could then be accessed. Throughout the nineteenth century, forging alliances in the form of "sister" or "twin" city agreements was a strategy that also characterized German-populated communities (Seewann 2013: 84-87).

The nineteenth century also saw the growing desire by Hungary's state leadership to create a homogenous administration that would unify a diverse ethnic composition. This goal was primarily realized via linguistic means; beginning in the early nineteenth century, ethnic populations faced growing pressure to assimilate into mainstream society by speaking Hungarian. This form of linguistic nationalism naturally impacted schools, where minority languages were increasingly expelled from classrooms. With the exception of Transylvania, between 1867 and 1910 ninety percent of the German education institutions found in Hungary fell victim to the pressure to assimilate, a demand that was first reflected in culture and the press. As a new century was ushered in, this pressure entered the homes and families of Hungary's German communities, where a growing number of individuals saw the social and economic advantages in adopting Hungarian surnames. Originally members of what could be called a burgher class, Hungarian Germans could not resist the highly attractive offer of traversing the path of assimilation to assume a position as middle class citizens in Hungary's new nation state.

After the Austro-Hungarian Monarchy collapsed in 1918, many German-inhabited territories were scattered amongst newly founded successor states; this state of separation gave birth to a new, national sense of group identity that crossed regional borders. Although new state lines initially formed the basis for this sense of group identity, a few years later the concept of a German volk community that was capable of spanning any border arose. Consequently, the pre1914, traditional form of a Hungarian German identity that was loyal to the state, embued with a sense of Hungarianness and primarily present in the social classes found in rural village life became realigned in the formation of an ethnic group characterized by its German folk identity. Throughout the 1930s, families and village communities were divided by the rivalry that arose between following a traditional versus the radicalized model of identity; in fact, this debate sowed fiery debate and discord among the entire community of Hungarian Germans.

The concept surrounding the existence of a German volk was founded upon the idea that all Germans are members of a larger group that subsequently linked every German-inhabited territory to Germany, thereby forging a biologically-based unity. The next step was to prove this 
Márkus, Éva and Maya Lo Bello. "Mihály Lieb or Mihály Munkácsy? Developing Cultural Identity in Hungary’s German National Minority Schools." Hungarian Cultural Studies. e-Journal of the American Hungarian Educators Association, Volume 14 (2021): http://ahea.pitt.edu DOI: 10.5195/ahea.2021.426

concept's legitimacy, no matter the cost this entailed. As István Bibó expressively described it, this process was partly a form of defense against the chauvinism and impatience exhibited by majority populations who were unwilling to accept any right German minorities had for either self-governance or their own schools. In short, ethnic policies that emphasized Hungarianness and rights for the Hungarian majority led to discrimination and oppression that in turn fed the political radicalization of Hungary's German population. As Miklós Horthy's regency grew increasingly autocratic, the path to compromise could not even be traversed by individuals such as the literary historian, scholar and Minister of National Minorities, Jakob Bleyer (1874-1933). A recognized leader of the Hungarian German community, Bleyer strove for over a decade to further peace by means of Sonntagsblatt, an influential, German-language weekly paper he established in 1921, or the Magyarországi Németek Népoktatási Egyesülete [Ungarndeutscher Volksbildungsverein, 'Association for the Volk Education of Hungarian Germans'] that he founded in 1923. (Although a new language law passed on June 22, 1923 guaranteed the rights of minorities to use their native language in schools and government offices, Hungarian state, Church and education authorities continued to enforce Hungarian as the main tool of assimilation. It therefore comes as no surprise that Bleyer established the Association for the Volk Education of Hungarian Germans a mere three weeks after this new language law was mandated.) Unable to overcome what had become an altogether untenable position, Bleyer instead turned to strengthening ties with the German Empire. It must be emphasized that this change of orientation from Budapest to Berlin was in no way connected to national socialism since Bleyer aligned himself with Germany in the summer of 1932, before the national socialist movement rose to power in Germany. His decision was instead the result of the Hungarian government's impatience toward minority policies and unwillingness to reach any form of genuine compromise. It is for precisely this reason that Bleyer and his successor, Franz Anton Basch (1901-1946), felt forced to turn to the German Empire for intecession on behalf of protecting Hungary's German populations, even as these two leaders had their doubts regarding this road to direct confrontation. (Franz Anton Basch eventually had a role in World War II as a leader of Hungary's Volksbund movement.)

Beginning in 1937, Berlin was able to utilize the Volksbund movement to realize its power aims for Germans living outside of Germany Based on the politics of imperial expansion, the Third Reich's order regarding ethnic communities (Volksgruppenabkommen) passed on August 31, 1940 was directly connected to the bilateral agreement regarding ethnicities that was a part of the Second Vienna Award and thereby contributed to the later outbreak of World War II. From this point on, debates no longer focused on cohabitation among ethnic groups or the preservation of three-hundred-year-old traditions, but rather urged segregation, dissimilation or the establishment of a "Lebensraum" that was defined as a belonging to the people, yet was founded upon exclusion and strictly organized by means of women's leagues, youth associations and SS recruitment. Needless to say, these Hungarian German movements turned toward Germany for both economic and political direction. Founded in 1938, the Magyarországi Németek Népi Szövetsége [Volksbund der Deutschen in Ungarn, 'People's Alliance of Hungarian Germans'] had formed a ideologically united front by 1940; with the arrogance typical of the national socialism movement, its leaders did not hesitate to declare who counted as "a true German" and who did not. In 1944, the SS actively recruited Hungarian Germans who were promised German citizenship in addition to keeping their Hungarian citizenship. (While the SS held two recruitment campaigns before 1944, participation in these was voluntary. After 1944 these campaigns were labeled "Muss-SS" ['Must-SS'] due to their mandatory nature.) In 
Márkus, Éva and Maya Lo Bello. "Mihály Lieb or Mihály Munkácsy? Developing Cultural Identity in Hungary’s German National Minority Schools." Hungarian Cultural Studies. e-Journal of the American Hungarian Educators Association, Volume 14 (2021): http://ahea.pitt.edu DOI: 10.5195/ahea.2021.426

September 1944, fifty-five thousand men between the ages of eighteen and fifty were conscripted into the Waffen SS (Seewann 2012: 289-290). Once the Third Reich had fallen, the gross, political misturn that was taken by minority German leaders forced Central and Eastern Europe's Germans to flee their homes, endure persecution and bear the wrongful burden of collective guilt while facing the destruction of values, traditions and accomplishments that had been built and preserved for hundreds of years (Seewann 2013: 89-90).

As the Soviet Army occupied Hungary in the autumn of 1944, individuals bearing German surnames were already being rounded up for forced labor. While Hungarians were also captured, anyone of German descent was particularly likely to be taken to the Soviet Union. In some instances, Hungarians were only "added" to the deportees after it had become clear that the number of Germans was insufficient. Even as late as 1949, only two thirds of those taken for málenkij robot ['a bit of work'] had returned home. As undeniably traumatic as the Soviet labor camps proved to be, the mass deportation of Hungarian Germans represented a far greater catastrophe: on May 26, 1945, the Hungarian government requested approval from the former Allied Forces to expel all Hungarian Germans from the country's territory. This permission was granted on August 2, 1945 as a part of the Potsdam Agreement. In a decision founded upon the collective guilt that all Germans were made to bear for World War II, Hungary's German communities were "resettled." This order was carried out against any individual who had listed himself or herself as being an ethnic German fluent in the German language in the 1941 census. Whether peasant farmers or middle-class citizens, Hungarian Germans were made the scapegoat for Hungary's participation in the war and the Holocaust. Labeled as fascists, the sváb were collectively punished for the tragedy that was World War II in a move that resulted in the deportation of 220,000 Hungarian Germans while roughly the same number were allowed to remain in Hungary. In 1946, 120,000 Hungarian Germans were forced out of Hungary to the American occupied zone located in Baden-Württemberg, Bavaria and Hessen. Between 1947 and1948, an additional fifty thousand individuals were deported to the Soviet occupied zone. This period of persecution not only comprised a loss of rights, discrimination and total demoralization for this population but it also destroyed the traditional forms of ethnic cohabitation that had characterized countless villages and cities in Hungary (Seewann 2013: 8891).

Today, estimated to number approximately two hundred to two hundred-fifty thousand individuals, Hungarian Germans comprise the second largest ethnic group in the country at 2.5\% of the total population. While they are commonly referred to as svábok ['Swabians'], they are actually Bavarian, Frank or Alemannic, to mention a few of the peoples who immigrated to Hungary from German-speaking territories that were located throughout all of the German Empire's southern and western regions in the eighteenth century. (Peoples from the German Empire's northern and eastern regions did not immigrate to Hungary.) Their widespread dispersion is one reason why a uniform dialect never emerged; utterly divergent, linguistic variants are spoken in various regions. Furthermore, the various dialects they speak display "mixed" linguistic features that developed in Hungary and are therefore unknown in Germany. Today, Hungarian German communities reside in different parts of the country, such as the area surrounding Buda, the Bakony Mountains, the counties of Tolna or Baranya and the western border region of Hungary. The deportation of these communities between 1946 and 1948 caused an immeasurable rupture in the history of Hungarian Germans: once half of this population had been expelled from the country, their unique culture preserved in secluded, rural communities collapsed. After 1945, speaking German was furthermore forbidden by Hungary's political 
Márkus, Éva and Maya Lo Bello. "Mihály Lieb or Mihály Munkácsy? Developing Cultural Identity in Hungary’s German National Minority Schools." Hungarian Cultural Studies. e-Journal of the American Hungarian Educators Association, Volume 14 (2021): http://ahea.pitt.edu DOI: 10.5195/ahea.2021.426

leadership, a factor that significantly restricted families from passing down their unique dialect to the next generation. Until their rights were reinstated in 1950, Hungarian Germans were stripped of their citizenship Since parents no longer spoke their native German dialect with their children, the following generations were only fluent in Hungarian. Although it is likely that the additional processes of urbanization, industrialization and social mobilization would have contributed to the gradual decrease in Hungarian German dialect usage as occurred in the histories of other ethnic groups (such as Slovaks, Romanians, Croatians, Serbs) in Hungary, the fact remains that it is impossible to state whether Hungarian German dialects would have followed the same path or not. On its own, mass deportation was enough to cause the very abrupt and extremely drastic disappearance of Hungarian German dialects. After so many towns and communities were emptied of Hungarian Germans, the legal discrimination experienced by those who remained in Hungary created an atmosphere of fear the effects of which are still obvious today among older individuals who remain noticeably reluctant to speak German or declare themselves as German. Today's tragic state of linguistic loss is therefore a direct consequence of historical trauma combined with discrimination: currently, the only individuals who are native speakers of a Hungarian German dialect are seventy or eighty years in age (Márkus 2016: 164).

To provide a statistical perspective of the nearly immediate, linguistic and cultural calamity wrought by deportation, in the 1941 census 475,491 individuals viewed themselves as native speakers of German while 302,198 categorized themselves as ethnically German. During the 1949 census, these two categories were chosen by a mere total of 23,000 individuals (Márkus, Gölcz 2018: 56). After communities were torn apart by enforced deportation, familes only had themselves to depend upon; those who remained in Hungary faced both political and economic discrimination. These conditions only eased roughly a decade after the end of World War II, at which point villages with German minority populations gradually gained access to German-language education. In 1955, the first program to train educators in teaching minority language classes was founded in Pécs. With the easing of Stalinism, the Magyarországi Német Dolgozók Kultúrszövetsége [Kulturverband der Deutschen Werktätigen in Ungarn; 'Cultural Association of German Workers in Hungary'] also formed in 1955, followed by the Magyarországon élö Németek Demokratikus Szövetsége [Demokratischer Verband Ungarnländischer Deutscher; 'Democratic Association of Germans Living in Hungary'] in 1969. The year 1978 saw the formation of Magyarországi Németek Demokratikus Szövetsége [Demokratischer Verband der Ungarndeutschen; 'The Democratic Association of Hungarian Germans'], while the Magyarországi Németek Szövetsége [Verband der Ungarndeutschen; 'Association of Hungary's Germans'] began operations in 1989. After the 1994 governmental elections, one hundred-sixty-four German minority municipal councils were established; in this same year, the Association of Hungary's Germans was dissolved in order to be replaced by the Magyarországi Németek Országos Önkormányzata [Landesselbstverwaltung der Ungarndeutschen; 'National Municipal Council of Hungary's Germans'] (Manherz, 1998).

As a result of the emergence of the municipal council system for Hungary's ethnic groups, hundreds of national minority preschools, schools and various other educational institutions operate in Hungary. The task of these minority schools is to maintain the native language and culture of Hungary's historic ethnic groups, such as Slovaks, Romanians, Serbs, Croatians, or the subject of this study, Hungarian Germans. German national minority schools are characteristically found in areas populated by Hungarian Germans, such the villages surrounding Budapest or the counties of Komárom-Esztergom, Tolna and Baranya. Approximately five secondary schools (such as the Klára Leőwey Secondary School in Pécs, the 
Márkus, Éva and Maya Lo Bello. "Mihály Lieb or Mihály Munkácsy? Developing Cultural Identity in Hungary’s German National Minority Schools." Hungarian Cultural Studies. e-Journal of the American Hungarian Educators Association, Volume 14 (2021): http://ahea.pitt.edu DOI: 10.5195/ahea.2021.426

UBZ in Baja, the Német Nemzetiségi Gimnázium ['German Minority Secondary School'] in Pesterzsébet, the Friedrich Schiller Secondary School in Pilisvörösvár and the László Lovassy Secondary School in Veszprém) also allow students to specialize in German minority education while universities offer teachers' training programs for the purpose of ensuring instructors qualified in educating minority groups. Governmental policies promote and fund the efforts of national minority schools by providing supplementary, normative support for these institutions and paying national minority educators an additional premium for their work. During the 2019/2020 academic year, the Hungarian government dedicated a significant sum toward the training of national minority preschool educators. Native language instructors are financed by the Hungarian government and the German minority municipal council supports each university student with a monthly stipend.

Due the tragic, post-World War II circumstances mentioned previously, in the case of Hungarian Germans it is not possible to speak of native language education: instead, recent generations must learn their heritage dialect as a second or foreign language. Since the children who attend a Hungarian German minority school have grown up speaking Hungarian at home, it is the school's task to decide whether the German vernacular is taught as a second or rather foreign language. In short, children from Hungarian German communities "relearn" their ancestors' language, rather akin to other efforts around the globe, such as the immersion programs spearheaded by indigenous schools in Canada and the United States (Morcom, Roy 2017), Ireland's efforts to bring back Irish (Slomanson 2012), Wales's language revitalization program via Welsh-medium schools (Williams 2014) and language education in Basque (Echeverria 2003). In contrast to the less formal Welsh-medium play groups or day nurseries found in Wales for children ages 0-4, Hungary provides formal, state-supported, preschool education at national minority programs targeting children ages three to six. These preschools are where most future students of German national minority schools are exposed to their heritage language for the first time, albeit this introduction occurs through the medium of both written and spoken Hochdeutsch since many Hungarian German dialects have not remained intact. The only feasible way to maintain some aspects of the heritage dialect is to teach students in Hochdeutsch while adding words, phrases, songs or stories that represent the local Hungarian German dialect. Unlike many of the language revitalization programs mentioned above, in Hungarian German minority education the ultimate goal is not for students to become native speakers of a Hungarian German dialect. Instead, the aim is for Hungarian German children to become conscious of the differences between their heritage dialect and Hochdeutsch while gaining pride in their ethnic background. Since the introduction of German minority education, generations of Hungarian German students have grown up with a knowledge of their heritage culture and are familiar with their ancestor's songs and dances, but do not usually display the fluency associated with native language acquisition since their German dialect is not spoken at home following the extensive degree of assimilation that Hungarian German families have undergone. It is therefore typical for these children to speak Hungarian among themselves or reply in Hungarian to questions that were posed in German.

Familiarizing students with German heritage dialects and the history of Hungary's German minority groups forms an essential aspect of both formulating and strengthening their ethnic identity. Published in 2010, the document entitled Gyökerek és szárnyak. A magyarországi németek nevelési, oktatási és közmüvelödési programja ['Roots and Wings: A Program for the Education and Instruction of Hungary's Germans'] expresses the following education aims: 
Márkus, Éva and Maya Lo Bello. "Mihály Lieb or Mihály Munkácsy? Developing Cultural Identity in Hungary’s German National Minority Schools." Hungarian Cultural Studies. e-Journal of the American Hungarian Educators Association, Volume 14 (2021): http://ahea.pitt.edu DOI: 10.5195/ahea.2021.426

Together with a familiarity of modern culture in German-speaking territories today, an advanced knowledge of German, the cultivation of local dialects and customs and an awareness of both the past and present of Hungarian Germans today are all integral aspects of the Hungarian German identity" [A német nyelv magas szintü ismerete, a helyi nyelvjárások és szokások ápolása, az ismeretek és eszmecserék a magyarországi németek történetéröl és jelenéröl a német nyelvterület modernkori kultúrájának ismeretével együtt a magyarországi német identitás nélkülözhetetlen részét képezi] (Erb et al 2010: 8).

The goals expressed in this document coincide with the wishes of those Hungarian German parents who still possess knowledge of their ethnic background and are proud of their German ancestry, yet were not able to learn the language and culture from their parents. It must also be emphasized that, regardless of their different ethnic background, Hungarian families are quite willing to send their children to a German minority school, where students are exposed to a high level of German-language instruction. Although there is a dearth of statistics regarding how many non-German families choose these schools, it can be said that many more students attend German minority schools compared to the number of individuals who identify as ethnic Germans in the national census. According to law, the children of Hungarian German families are to be prioritized in the acceptance process since non-German children can only be registered if there are not enough Hungarian German children to fill the available spaces (http://nemzetisegek.hu/2020/09/14/nemzetisegi-ovodai-nevelesben-illetve-nemzetisegi-iskolaineveles-oktatasban-valo-reszvetelhez-szukseges-nyilatkozat-es-kerelem-minta). As can be expected, non-German families place less importance upon learning Hungarian German customs and dialects compared to Hungarian German parents.

\section{Hungarian German Minority Schools and the Ulmer Schachtel as a Community Symbol}

To provide a few examples of some of the institutions responsible for preserving Hungarian German dialects and culture, a village near Budapest, Törökbálint (Grossturwall), operates a German national minority preschool. Here, the descendents of German settlers who first arrived in the eighteenth century can attend the Csupasziv ['Heartful'] Bilingual Preschool, or Ein Herz für Kinder https://www.csupaszivovi.hu/app/cms/TorokbalintApp/csupasziv. Another town not far from Budapest, Solymár (Schaumar) contains the Solymári Hunyadi Mátyás Német Nemzetiségi Általános Iskola, Alapfokú Müvészeti Iskola ['Mátyás Hunyadi German National Minority Primary School and Elementary Art School of Solymár'], an institution with a past that stretches back hundreds of years. (Germans settled in Solymár following the removal of Ottoman forces from the territory of the Hungarian Kingdom.) 
Márkus, Éva and Maya Lo Bello. "Mihály Lieb or Mihály Munkácsy? Developing Cultural Identity in Hungary’s German National Minority Schools." Hungarian Cultural Studies. e-Journal of the American Hungarian Educators Association, Volume 14 (2021): http://ahea.pitt.edu DOI: 10.5195/ahea.2021.426

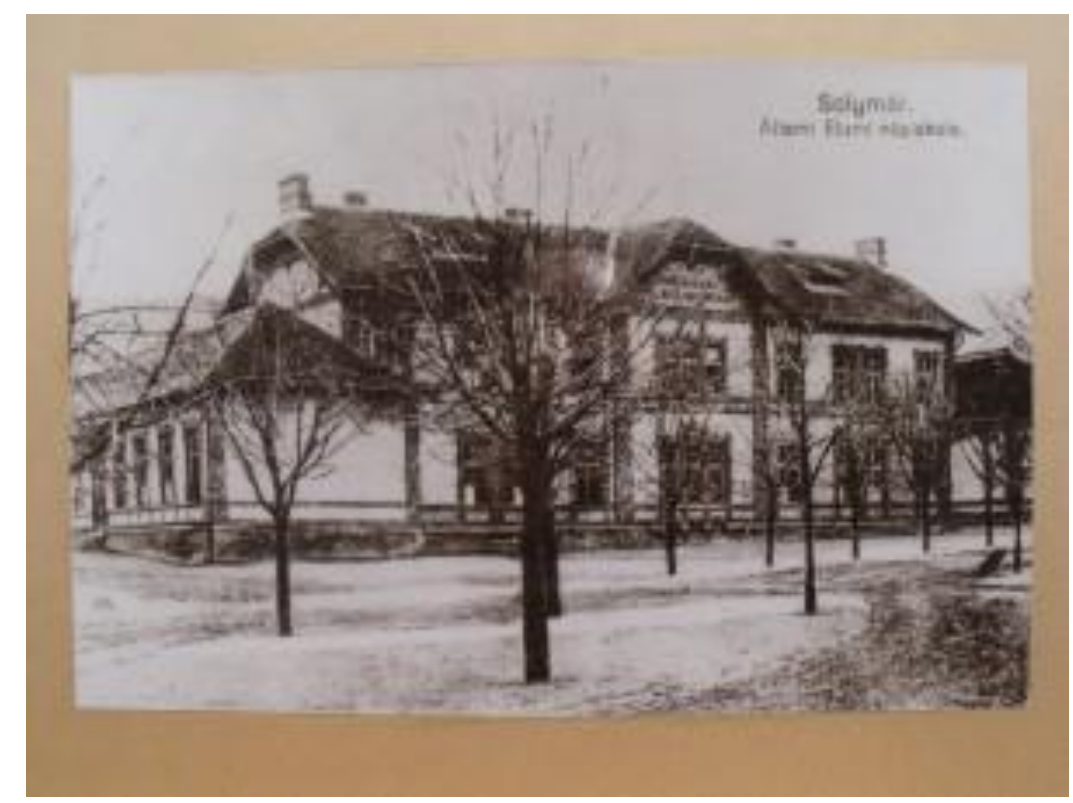

Solymár's School Building

http://www.solymarialtalanos.hu/alapiskola/az iskola tortenete/

For the purpose of this analysis of the role népismeret ['folk education'] plays in strengthening cultural identity, a project launched by the secondary school at the Magyarországi Németek Általános Müvelödési Központja ['Center for the General Cultural Education of Hungary's Germans'] (https://www.mnamk.hu/) in the city of Baja (Baje) deserves a more detailed examination. This center contains both a secondary school and vocational program as well as a boarding school for rural students who reside at the center full-time. Its Ulmer Schachtel project provides an excellent example of how the Ulmer Schachtel, or "Ulm barge" that Danubian Swabians used to emigrate to Hungary in the eighteenth century could become a unifying symbol of Hungarian Germans and their dual identity. Its name was coined by a contemporary representative in Stuttgart who, due to their simple construction, labeled these Danube boats "boxes" or Schachtel. In Ulm they were actually called Ordenare in reference to the fact that they had been ordinari or regularly scheduled vessels running between Ulm and Vienna since 1712. Their structure was quite functional, given that the boat was only used for sailing in one direction: to head downstream. Upon arrival at its destination, the boat was disassembled and sold as wood. Due to its flat planking, this type of boat could virtually hug the riverbank while progressing down the Danube. The slanting black and white stripes on its body are not only characteristic, but also improved the vessel's visibility. Over time, the size and shape of an Ulmer Schachtel was constantly changed and even reached a length of fifteen to twenty-two meters and a width ranging between two and five meters. A wooden hut located in the barge's center provided settlers with shelter during inclement weather. A pair of poles found in the prow and the stern were used to direct the boat, together with oars.

In recognition of the important role Ulmer Schachtel had in the history of Hungarian Germans, the German Municipal Council of Baja, the Public Endowment for Germans of Bácska and the Cultural Society of Bácska Germans joined forces with the Center for the General Cultural Education of Hungary's Germans to erect an exact replica of an original, Ulm barge in Baja. Its presence fulfills the following three purposes: 
Márkus, Éva and Maya Lo Bello. "Mihály Lieb or Mihály Munkácsy? Developing Cultural Identity in Hungary’s German National Minority Schools." Hungarian Cultural Studies. e-Journal of the American Hungarian Educators Association, Volume 14 (2021): http://ahea.pitt.edu DOI: 10.5195/ahea.2021.426

1. It stands in memory of those Hungarian German ancestors who, in the eighteenth century, sailed primarily in ships like these from territories located in South and Central Germany to Hungary. The skills and diligence of these immigrants had a significant role in rebuilding the nation after the destruction wrought by the Ottoman conquest. This memorial is meant to remind future generations of their heritage while representing their continued, firm commitment to their birthplace of Bácska.

2. The Ulmer Schachtel serves as a tourist attraction within both Baja and Bács-Kiskun County, places that are both home to many Hungarian Germans as well as destinations for numerous foreign visitors. Given that this Ulmer Schachtel is the only replica built according to original dimensions, it is hoped to attract many more tourists to Baja.

3. Its most important aim is to provide a site for educating visitors as a unique form of an educational, outdoor "nature path" that can be used as an effective backdrop for history or folk education lessons that familiarize students with the history and culture of Hungary's Germans. The enclosed structure on board remains open to students and tourists alike; individual visitors may also participate in the projects and exhibits that take place inside.

https://www.mnamk.hu/ulmer-schachtel/koncepcio.
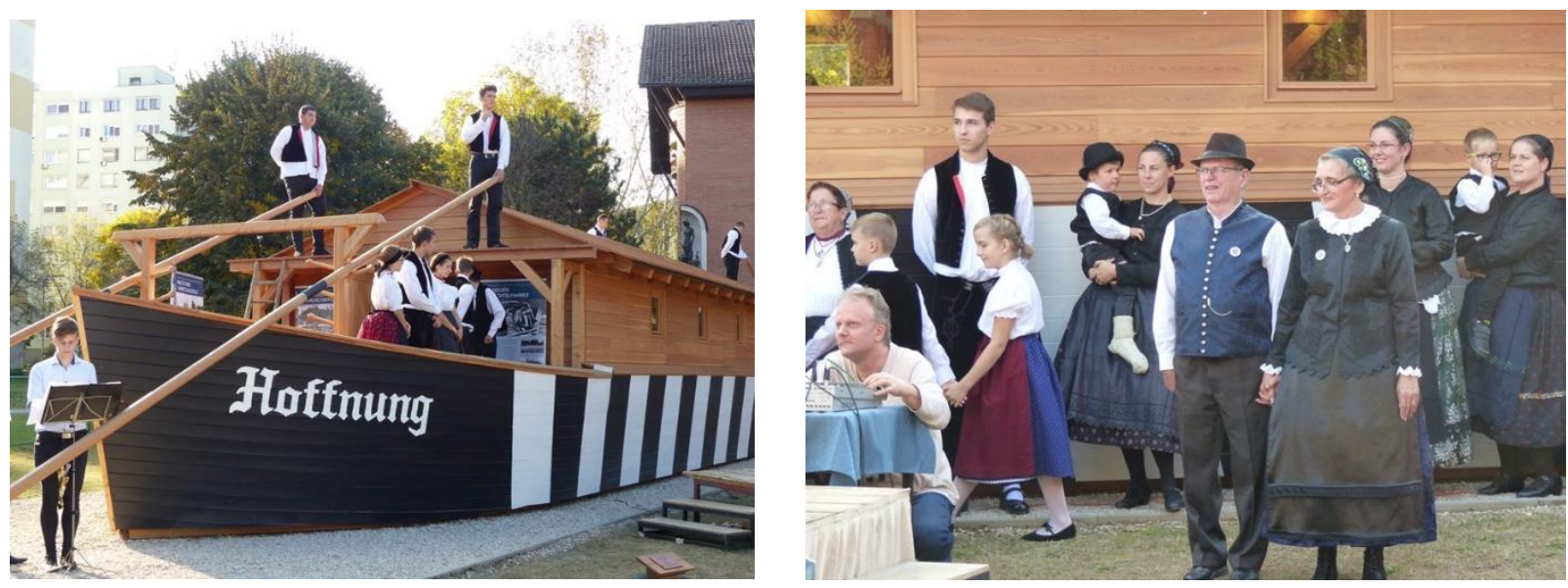

The Ulmer Schachtel in Baja

https://mnamk.hu/cgblog/295/Remeny-az-MNaMK-udvaran?page=cgblog/295/Remeny-azMNaMK-udvaran

Taken at the Ulmer Schachtel's inauguration, the pictures above amply demonstrate that this occasion inspired students, guests and members of the local community to don their national costume, clothing that is only worn for special occasions these days. The importance of dance and music can also be seen on this barge that symbolically acts as a kind of "Ark" for the Hungarian German language and culture.

\section{State Guidelines for Minority Education}

The Hungarian state plays a central role in determining the education system, so that no matter its affiliation as a state, parochial or minority institution, each school must follow these regulations. Ministerial orders also regulate what education opportunities are afforded members 
Márkus, Éva and Maya Lo Bello. "Mihály Lieb or Mihály Munkácsy? Developing Cultural Identity in Hungary’s German National Minority Schools." Hungarian Cultural Studies. e-Journal of the American Hungarian Educators Association, Volume 14 (2021): http://ahea.pitt.edu DOI: 10.5195/ahea.2021.426

of minority communities. Schools for Hungary's national minorities can be placed in three categories. Based upon the order issued by EMMI [Emberi Erőforrások Minisztérium; 'Ministry of Human Resources'] in 2012, the educational directives for minority preschool and schools have been summarized in the following points (http://net.jogtar.hu/jr/gen/hjegy_doc.cgi?docid=A1300017.EMMI):

1. With the exception of Hungarian language and literature or foreign language lessons, instruction in these institutions is conducted in the minority language;

2. These institutions are bilingual, given that at least three subjects found in the pedagogical program must be taught in the minority language. Other than providing language and literature instruction in the native language, totaling fifty percent of the number of those compulsory lessons per week that are not related to Hungarian language and literature or foreign language education;

3. These institutions are typically sites for language instruction where language is taught in observance of both traditional and expanded forms of minority language education;

a) In the traditional form of language education for minorities, the language of instruction is Hungarian while the minority language and literature must figure among the subjects to be taught beginning with first grade;

b) As regards the expanded form of language instruction in minority education, the aim is to prepare students for bilingual minority or native forms of education. Students study the minority language and literature while instruction in an additional, three subjects must be made available in the minority language. The percentage of minority language and literature lessons combined with other subjcts taught in the minority language must comprise at least thirty-five percent of the total number of lessons (Márkus 2014: 322).

While the significance of the state's impact on education is undeniable, the nemzetiségi önkormányzat ['national minority municipal council'] system is also worthy of attention for its role in upholding minority communities' rights and interests. In accordance with the law regulating the rights of minorities, these municipal councils are elected during locally held, municipal elections that also determine, for example, the composition of the town council. (The most recently held election of this type took place in October, 2019.) National minority municipal councils are responsible for representing the interests and rights of the local minority community, including access to language education and the preservation of cultural heritage. In the case of Hungarian Germans, this system is overseen by the Magyarországi Németek Országos Önkormányzata ['National Municipal Council for Hungarian Germans,' heretofore referred to as MNOÖ in this paper], an institution that was elected by the German minority's electoral council on March 11, 1995 following the establishment of the national minority municipal council system in December, 1994. Based upon the $179^{\text {th }}$ Law for National Minorities of 2011, MNOÖ is meant to realize a modern approach to minority policies; its primary aim is to preserve and support Hungarian Germans' language, intellectual heritage, historical traditions and identity. In the area of culture, MNOÖ supports the maintenance and continued development of the Hungarian German language, a goal it realizes by aiding German-language education within the Hungarian school system. Its international connections serve the purpose of providing exchange programs by means of partnership networks and programs. Primarily, MNOÖ carries out activities in realizing cultural autonomy by operating and maintaining its own Hungarian German institutions. It total, MNOÖ oversees four hundred-two local minority municipal 
Márkus, Éva and Maya Lo Bello. "Mihály Lieb or Mihály Munkácsy? Developing Cultural Identity in Hungary’s German National Minority Schools." Hungarian Cultural Studies. e-Journal of the American Hungarian Educators Association, Volume 14 (2021): http://ahea.pitt.edu DOI: 10.5195/ahea.2021.426

councils while also acting as the umbrella organization for over five hundred cultural groups and Hungarian German associations (http://www.ldu.hu/page/69).

The document entitled Steh dazu! A Magyarországi Németek Országos Önkormányzata stratégiája 2020-ig ['Stand For Your Rights! The Hungarian German National Municipality Council's Strategy Till 2020'] expresses its aims in the following manner:

Our essential public policy aim is to develop a fair politics of memory regarding Hungarian Germans. This is necessary because neither Hungary's education system nor public opinion is aware of those latest, academic findings that would reflect a balanced view of the German minority's history, accomplishments and contributions to Hungary's development. We aim to frame our own, mutual narrative in a way that is exempt form dogma. This narrative will provide the context for analyzing and evaluating the history and goals of our important historical figures and institutions. Our essential purpose is for members of mainstream society who are not a part of the German community to become acquainted with our past.

To underline why Hungarian Germans are eager to fill this gap in knowledge, the tenthgrade history textbook used in secondary school only mentions the settlement of German peoples in Hungary. In fact, only one, five-page lesson bearing the rather unexciting title of " $A$ XVIII. századi népességnövekedés és etnikai következményei" ['Population Growth in the Eighteenth Century and Its Ethnic Consequences'] addresses the issue at all, albeit in a way that lumps many ethnic groups into one, crowded summary. While the settlement of Slovak, Ruthenian, Romanian and Serb peoples is individually discussed in separate subchapters, the immigration of German peoples does not receive the same treatment, despite the fact that Germans arrived in the largest numbers.

Although the state maintains the most educational institutions, the municipal council system that is operated by Hungary's national minority groups has the ability to take charge of preschools or schools and have done so in a few cases. The most recent instance occurred not far from Budapest in Budakeszi (Wudigess), a small city with a Hungarian German population. Beginning in September 1, 2020, this school functions as an independent institution that is operated by the Budakeszi Város Német Nemzetiségi Önkormányzata ['Municipal Council for the German Minority in the City of Budakeszi']. The original school was divided into two institutions, with one half falling under the aegis of the local, Hungarian German municipal council. In possession of adequate fiscal backing, the municipal council immediately set to renovating and modernizing its half of the building, an effort that automatically garnered attacks and opposition on the part of KLIK [Klebelsberg Központ; 'Klebelsberg Center'], the government authority responsible for overseeing educational institutions in Hungary.

Since 2005, the Hungarian German community also operates its own Institute of Pedagogy in Pécs. In January 2021, the Institute of Pedagogy became the Német Pedagógiai és Módszertani Központ [Ungarndeutsches Pädagogisches und Methodisches Zentrum; 'Center for German Pedagogy and Methodology'] and is maintained by the MNOÖ. This institution's task is to provide methodological support for educators, from preschool to secondary schools. Its website contains a wealth of curricula, teaching syllabi, methodological handbooks, textbooks and workbooks, other than regularly offering professional training sessions (https://www.udpi.hu/hu/). For decades, Eötvös Loránd University's Faculty of Preschool and Primary Education (ELTE TÓK) has been a flagship institution in training future preschool and 
Márkus, Éva and Maya Lo Bello. "Mihály Lieb or Mihály Munkácsy? Developing Cultural Identity in Hungary’s German National Minority Schools." Hungarian Cultural Studies. e-Journal of the American Hungarian Educators Association, Volume 14 (2021): http://ahea.pitt.edu DOI: 10.5195/ahea.2021.426

primary teachers to head German minority classrooms. ELTE TÓK's three-year preschool program or four-year program for primary educators prepares teachers to educate children either in a German minority preschool or throughout the first four years of primary school. Future teachers are not only taught how to expose young children to their heritage, German language, but also enables them to hold activities or school lessons in areas such as music, physical education or natural science in Greman. Unfortunately, the bulk of this training program is conducted in Hungarian, thereby leaving an insignificant number of classes open to developing German-language skills; it must be admitted that few students are able to complete the program with a high proficiency in Hungarian German.

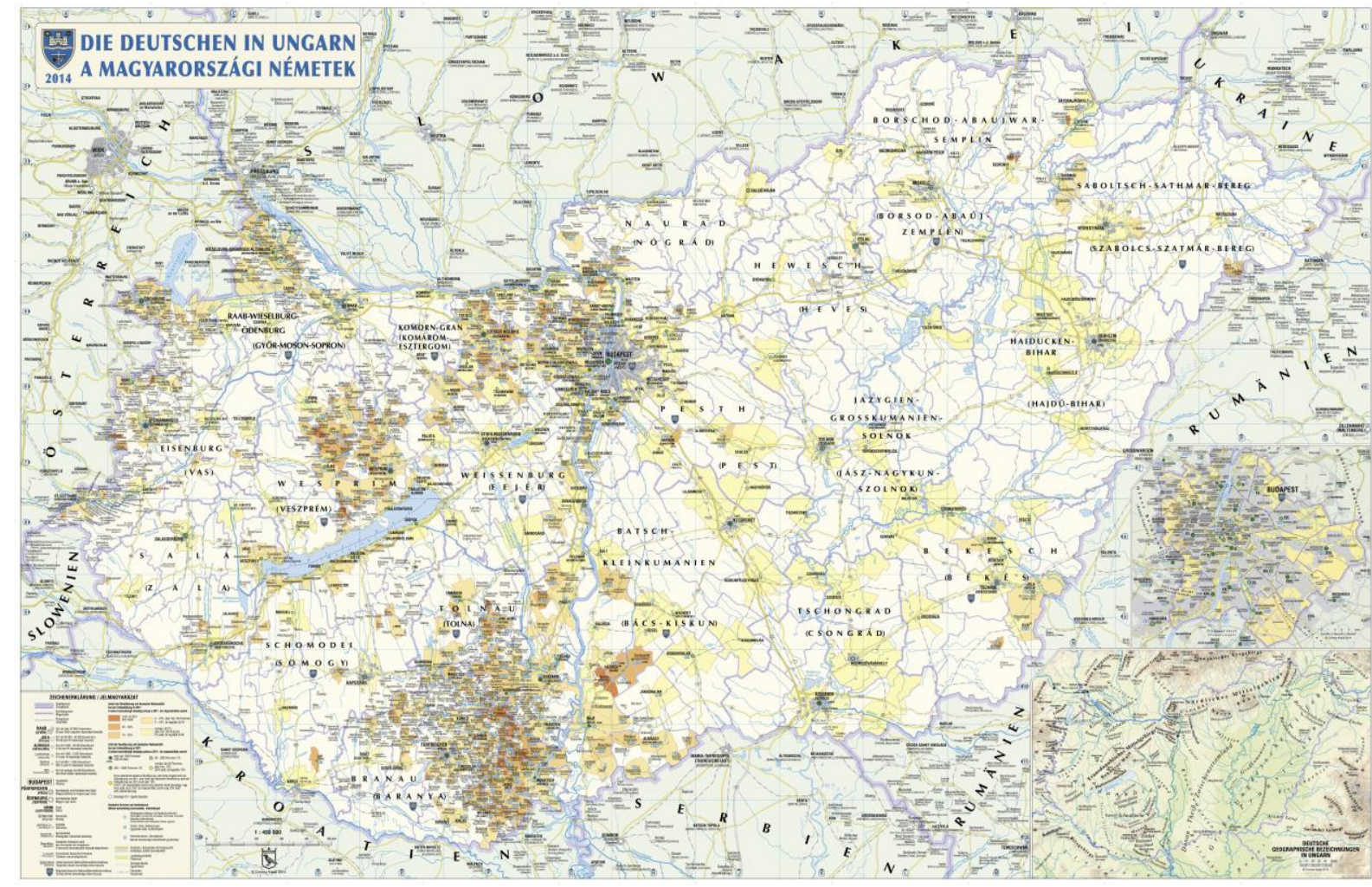

Map depicting concentrations of Hungarian German populations found in towns indicated in yellow. The more intense the shade of yellow, the larger the percentage of Germans is within the given municipality. Source: http://www.ldu.hu/page/69

\section{The Role of Folk Education in Strengthening Cultural Identity}

In Hungary's school system, the most suitable subject for developing and strengthening cultural identity is folk education. Held once a week, the subject of folk education is intended to familiarize students from grades one to twelve with traditions and cultural values. In Hungarian German institutions, the task of Hungarian German folk education classes is to reinforce a sense of identity and cultural values. While folk education classes for Hungarians begin with the honfoglalás, i.e., the arrival of Magyar tribes in the Carpathian Basin 895 A.D., for Hungarian German students their past examines the immigration of various German peoples to Hungary in the eleventh or eighteenth centuries. Other than typical Hungarian German customs and traditions (such as holiday traditions for St. Lucia Day, Christmas or Easter that diverge from 
Márkus, Éva and Maya Lo Bello. "Mihály Lieb or Mihály Munkácsy? Developing Cultural Identity in Hungary’s German National Minority Schools." Hungarian Cultural Studies. e-Journal of the American Hungarian Educators Association, Volume 14 (2021): http://ahea.pitt.edu DOI: 10.5195/ahea.2021.426

Hungarian customs), their instruction additionally examines the expulsion of Hungarian Gemans from Hungary after WWII and the fates of the thousands of Hungarian Germans who were pressed into prison labor, or málenkij robot, in the Soviet Union. Additional topics examine the typical architecture of Hungarian German peasant homes, Hungarian German folk costumes and the trades and crafts traditionally done by Hungarian Germans. From the point of view of methodology, educators are urged to employ a creative and activity-centered approach to instructing students (such as Freiarbeit ['independent work1], the setting up of educational "stations" that entice students to move from topic to topic, workshops, activities conducted via museum pedagogy, or school projects) because this kind of an approach exposes students to the kinds of vibrant, personal experiences that they would otherwise not be able to access within their own environment.

In effect since September 2013, the kerettantervek ['national curricular guidelines'] for all subjects taught in Hungary (http://www.udpi.hu/hu/dokumentumok/kerettantervek/kerettantervek-2013-szeptembertol) concretely determine a role for Hungarian German history in minority education. According to these curricular guidelines, in Hungarian German institutions, the subject of folk education furthers "the integral elements comprising identity, such as the possession of a high level of linguistic ability, the preservation of local dialects and customs and knowledge of both the past and present.” The new National Basic Curriculum that came into effect in 2020 furthermore contains content guidelines and new curricula; from the point of view of the present examination, only those aspects connected to education for German minorities will be reviewed (https://www.oktatas.hu/kozneveles/kerettantervek/2020_nat/nemzetisegi_neveles_oktatas_kerett antervei/nemet). As of the 2020/2021 academic year, these guidelines are to be introduced progressively, beginning in the first, fifth and ninth grades.

The 2020 curricula guidelines for German folk education relay the following information: "Language and culture form an integral basis in the preservation and affirmation of the identity of Hungary's German minorities. As a consequence of decades of a discernibly advanced state of assimilation, educational institutions have an increased role in transmitting language, culture and identity." The passage continues on to state that, "An advanced knowledge of the language, the cultivation of local dialects and customs and an awareness of both the past and present are all integral aspects of identity. In today's modern world, learning by means of human connections is just as important as attaining knowledge, information or developing strategies for action. For Hungary's national minorites this fact possesses particular significance given their access to two native languages. It must, however, be taken into consideration that educational institutions cannot build upon linguistic skills brought from home due to the process of assimilation mentioned above."

The most recent curricular guidelines for Hungarian German folk education additionally suggest that minority students should be "inducted" into their heritage's most important traditions and cultural or lifestyle elements in an environment that will ensure a more personal experience. At first, for example, educators should explain the differences between Hungarian and Hungarian German customs, such as the fact that the latter did not typically celebrate the folk tradition of locsolkodás on Easter Monday. In certain regions, German families hung the Christmas tree from the ceiling, over the holiday table, a custom that was held in some regions of Germany and even made its way to some German communities in the United States (https://www.meinetanne.de/blog/weihnachtsbaum-verkehrt-herum-haengen). Their diets were typically based on the consumption of potatoes, beans and noodles cooked in simple ways, with 
Márkus, Éva and Maya Lo Bello. "Mihály Lieb or Mihály Munkácsy? Developing Cultural Identity in Hungary’s German National Minority Schools." Hungarian Cultural Studies. e-Journal of the American Hungarian Educators Association, Volume 14 (2021): http://ahea.pitt.edu DOI: 10.5195/ahea.2021.426

few ingredients. German towns and villages were known for their cleanliness and orderliness, and/with Germans were generally viewed as being handworking, diligent people who did not squander their resources. After the basic cultural identifiers listed above have been established, students can be exposed to aspects of Hungarian German history, ethnography, language, literature and media by means of activity-based and project-oriented methods. History, for example, is designated to grades seven and eight in elementary schools and for each year of secondary school. The following history topics are outlined for seventh- and eighth-grade classes: initial connections between Germans and Hungarians (eleventh century); the history of German settlement in Hungary (18th century) including its reasons and consequences, most important aspects, hopes and challenges. The topic of German people's settlement in Hungary appears again in the ninth and tenth grades. The difference between this process and the history of Hungarian tribes' entrance into the Carpathian Basin cannot be emphasized enough: the former comprises a completely alternate identity compared to that taught to Hungarian students. In these grades, students are expected to learn the route German settlers took from their original point of departure to Hungary. Based on the 2020 curricular guidelines, a new topic has been added to folk education courses for ninth- and tenth-graders: the many forms and systems of interaction that connected Germans and Hungarians from medieval times to the eighteenth century are to be explored by means of topics such as early Hungarian-German contact (eleventh and twelfth centuries), the emergence of urban centers, the burgher class, mining in the fourteenth and fifteenth centuries and the already-mentioned migration of German peoples in the eighteenth century.

The issue of Hungarian Germans' expulsion or deportation from Hungary is to be taught from eleventh to twelfth grades, "including the historical background to the deportation and expulsion of Germans, the underlying reasons for this and the subsequent impact on this minority's current situation; the topic is to be assessed in an objective and analytical way." Students are to be made aware of the fact that Hungarian Germans were collectively blamed for World War II, consequently nearly half of Hungary's 500,000 ethnic Germans were expelled from the country and forced to return to Germany. Their homes and property were confiscated; deportees had only a short time to pack roughly fifty kilograms of belongings into a bundle that they could then carry on their backs to their next destination. Their journey back to the "old country" took place in inhumane conditions, as they were packed into cattle cars and returned to the wreckage of postwar Germany. In 1946, deportees were delivered to the United States's occupied zone; once this area became full, they were instead settled within the Soviet Union's occupied zone. Hungarian Germans were deported until 1948; those who remained in Hungary regained their equal rights as Hungarian citizens in 1950. Exploring the connections between cause and effect via the study of individual fates and personal stories, preparing interviews with survivors, expressing and supporting a personal opinion, writing a journal based upon contemporary sources, viewing documentary films, visiting exhibits, conducting independent research and traveling to the memorials that commemorate the memories of those who were deported or taken for málenkij robot are the methods recommended for turning this past into a more relatable experience for students. 
Márkus, Éva and Maya Lo Bello. "Mihály Lieb or Mihály Munkácsy? Developing Cultural Identity in Hungary’s German National Minority Schools." Hungarian Cultural Studies. e-Journal of the American Hungarian Educators Association, Volume 14 (2021): http://ahea.pitt.edu DOI: 10.5195/ahea.2021.426

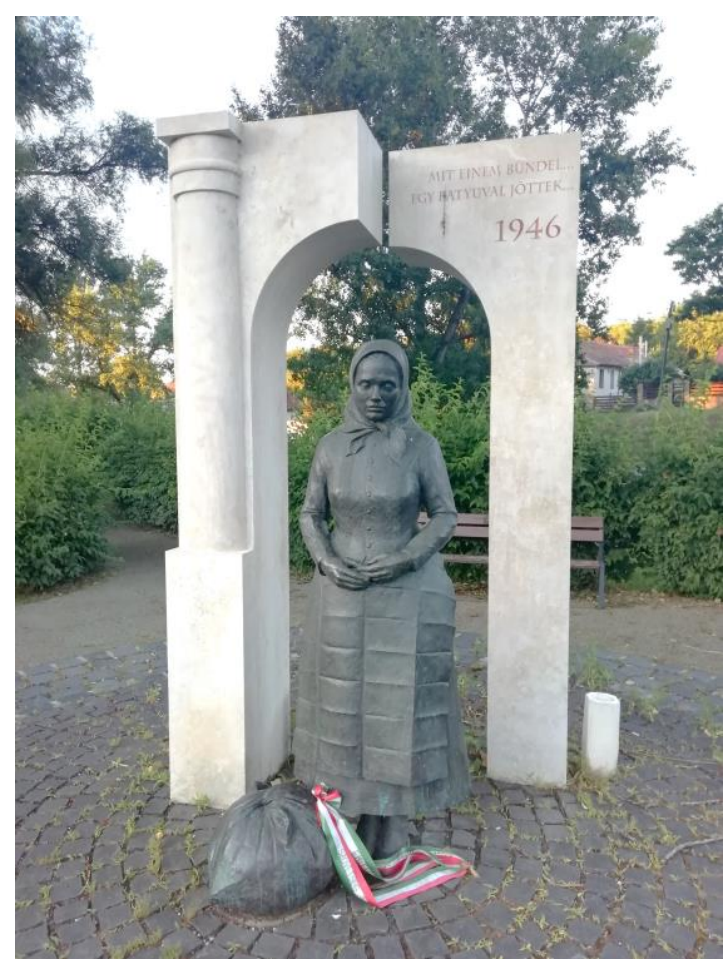

Memorial of the Deportation of Hungarian Germans, Biatorbágy (Wiehall-Kleinturwall). Photo: Éva Márkus

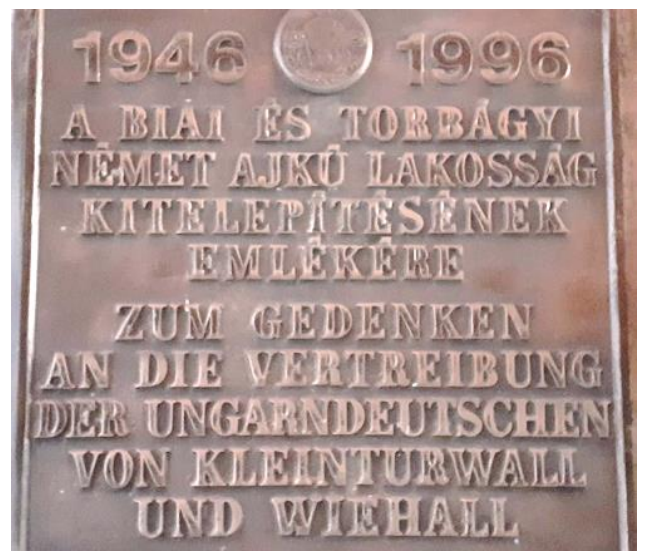

Memorial plaque in Biátorbágy, found on the building of the former train station from which Hungarian Germans were deported to Germany.

Photo: Éva Márkus

Overall, the curricular guidelines established for the folk education classes held at Hungarian German minority institutions can be used to explain the dual identity ( or Doppelidentitaet) that members of this community experience. "All of the national minorities native to the territory of the Republic of Hungary characteristically face the consequences of severe ethnic dispersion, a dual identity, advanced assimilation, the loss of the native language and a strong emotional and cultural connection to Hungary" [A Magyar Köztársaság területén honos nemzeti kisebbségek mindegyikére jellemzö az eröteljes szórvány helyzet, a kettös identitás, az elörehaladott asszimilálódás, a nyelvvesztés és az erös érzelmi, kulturális kötödés 
Márkus, Éva and Maya Lo Bello. "Mihály Lieb or Mihály Munkácsy? Developing Cultural Identity in Hungary’s German National Minority Schools." Hungarian Cultural Studies. e-Journal of the American Hungarian Educators Association, Volume 14 (2021): http://ahea.pitt.edu DOI: 10.5195/ahea.2021.426

Magyarországhoz] (Navracsics 2004: 37). In contrast to other ethnic groups in Hungary, Hungarian Germans do not identify as either German or Hungarian: they view themselves as Hungarian Germans who therefore possess a deep connection with their German roots and origin, yet remain fiercely loyal to their homeland, Hungary. It is quite an oversight that the folk education curriculum neglects to examine the 1848 Hungarian Revolution from the Hungarian German perspective: students are subsequently left unaware of the fact that Hungary's Germans fought on the side of Hungary rather than join the Habsburg forces. This historical decision comprises the first, mutually shared past experience for both Hungarians and Germans. Among the thirteen generals who were later executed in Arad by imperial decree, five were Hungarian Germans. Throughout the age of the Austro-Hungarian monarchy, Hungarian Germans actively participated in Hungary's economic prosperity by performing skilled labor in factories or providing other, significant services. To this day, the multitude of German words found in the vocabularies of many professions reflects the contributions Germans made to Hungary's industries, a phenomenon that attests to the overwhelming presence of the Germans who added their skills and abilities to these areas.

This paper contends that further steps must be taken in order to reverse the negative effect assimilation has had on maintaining German Hungarians' cultural heritage. One necessary solution is to demonstrate to children how their ancestors also experienced a dual identity by exploring the lives of famous individuals who, for the most part, are mainly presented from a purely Hungarian perspective. As the title of our examination indicates, the world-renowned artist, Mihály Munkácsy, exemplifies the phenomenon of "Hungarianizing" the pasts of people whose identites were dual. Rather than explore the fascinating nuances involved in being both Mihály Munkácsy and Lieb, textbooks, encyclodpedias cultural institutions and, indeed, public opinion reduce this complex life path to a set of parentheses: "Mihály Munkácsy (born Mihály Lieb, Munkács, 1844 - Endenich, 1900)." While Hungary's cultural historians acknowledge Munkácsy as one of the most significant figures in critical realism during the period of national Romanticism in Hungarian art, no mention is made of his German origins. Lacking this knowledge, it may come as a surprise that this "Hungarian" painter could so effortlessly manage to study art in Munich before moving to Dusseldorf in 1868 (Hambuch 1998: 447).

After reading Munkácsy's biography on the Internet (at https://www.hungart.hu/frames.html?/magyar/m/munkacsy/index.html, for example), students can then analyze the following summary of his life:

Artist, named Lieb until 1868, known as Munkácsi until 1880. Originally from Bavaria, his father, Leó Lieb, was a clerk at the salt mine in Munkács [Ukrainian: Munkacsevo; German: Munkatsch]; his mother was Cecília Reök. In 1848 the family moved to Miskolc. Munkácsy's artistic bent was already apparent in his early childhood. After his parents' premature death in 1850, he lived with his uncle, István Reök, a lawyer who was forced into silence after the 1848 Revolution and lived in modest circumstances in Békéscsaba. At the age of eleven, Munkácsy's guardian apprenticed him to a cabinetmaker. Abused by his master, the misery caused by physical and psychological punishments affected Munkácsy and his temperament for the rest of his life. After gaining his journeyman's certificate, Munkácsy went to Arad [Judeţul Arad], where he lived in poverty and fell ill until returning to his uncle in Gyula. While regaining his health, he learned how to draw from a local, German painter named Fischer. 
Márkus, Éva and Maya Lo Bello. "Mihály Lieb or Mihály Munkácsy? Developing Cultural Identity in Hungary’s German National Minority Schools." Hungarian Cultural Studies. e-Journal of the American Hungarian Educators Association, Volume 14 (2021): http://ahea.pitt.edu DOI: 10.5195/ahea.2021.426

[Festö, neve 1868-ig Lieb, 1880-ig Munkácsi. Apja, a bajor eredetü Lieb Leó sótiszt volt Munkácson, anyja Reök Cecília. 1848-ban a család Miskolcra költözött. Munkácsy festöi hajlama már kiskorában megnyilatkozott. Szülei korai halála után 1850-ben nagybátyjához, Reök István ügyvédhez került, aki a szabadságharc után hallgatásra kényszerítve, szerény viszonyok között élt Békéscsabán. A fiút 11 éves korában gyámja asztalosinasnak adta. Mestere durvaságai, a fenyítések okozta testi-lelki nyomorúság egész életére és kedélyére kihatott. Segédlevele megszerzése után Aradra ment. Nyomorgott, megbetegedett s visszatért nagybátyjához Gyulára. Lábadozása alatt rajzolni tanult Fischer ott élö német festötöl].

Class discussion could then focus upon reasons underlying why Munkácsy's biography is missing important details regarding his dual identity and raise awareness toward rectifying this type of omission. Students can then compare his Hungarian biography with the description of his life found on the German Wikipedia, where Munkácsy is also categorized as a Hungarian artist, yet far more details regarding his family background are also provided, including a family tree that traces his Bavarian ancestry to the town of Bártfa [Slovakian: Bardejov; German: Bartfeld] in 1730 (https://de.wikipedia.org/wiki/Mih\%C3\%A1ly_von_Munk\%C3\%A1csy). A further activity would be for the class to locate the most important Bavarian, Hungarian and European sites in Munkácsy's life, then illustrate these on a map while exploring how these towns and cities may have influenced his identity. Students can then compile an album of his works or create their own, artistic interpretations. The most important task is to draw children's attention to the fact that the great artist, Mihály Munkácsy, was also German, could utilize his German language ability to further his studies and is an example of Doppelidentitaet that will positively reinforce their own sense of Hungarian German identity.

Within Hungarian cultural studies, the areas of gastronomy, industry, music, theater literature, sports, architecture and medicine contain ample examples of other famous individuals who are not included in the curricular guidelines, yet can provide folk education teachers with the opportunity to strengthen their students' cultural identity. By studying the lives of others who possessed German ancestry yet were also stellar representatives of Hungarian culture, the next generation will not only gain an increased sense of pride in their Hungarian German heritage, but also be more motivated to learn their family's neglected dialect. Hungarian gastronomy, for example, cannot be considered without mentioning the Gundel family. Born in 1844 in Ansbach, Bavaria, János Gundel was a key figure in establishing the restaurant and tourism industry in Hungary. After arriving in Pest in1856, he eventually opened a restaurant in 1869 on Király Street. For thirty-five years, János Gundel served as head of the industrial association for Hungarian hoteliers and restaurant owners. Born in 1873 in Budapest, his son, Károly Gundel, authored numerous cookbooks; beginning in 1910, he first directed the Wampetich restaurant located in Budapest's City Park [Városliget], then, from 1927, headed the famous Hotel Gellért (Hambuch 1998: 453-454). Among Hungary's many famous confectioners, Rezső Hauer's popular pastry shop or Henrik Kugler's elegant patisserie on Vörösmarty Square must be mentioned. In 1884, Kugler's business was bought by his son-in-law, Emil Gerbeaud, who transformed it into the world-renowned Gerbeaud patisserie (Hambuch 1998: 454). Originally bearing the surname of Schmierl, József Törley opened Hungary's most famous champagne manufactory in Budafok (Hambuch 1998: 458); even today, no celebration would be complete without raising a flute of Törley champagne. Born in Vienna in 1841, the famous brewer, Antal Dreher, established the Dreher chain of breweries, a brand still present in Hungary today (Hambuch 1998: 457). When examining the world of manufacturing, mention must also be made 
Márkus, Éva and Maya Lo Bello. "Mihály Lieb or Mihály Munkácsy? Developing Cultural Identity in Hungary’s German National Minority Schools." Hungarian Cultural Studies. e-Journal of the American Hungarian Educators Association, Volume 14 (2021): http://ahea.pitt.edu DOI: 10.5195/ahea.2021.426

of András Mechwart and Árahám Ganz, both pioneers in Hungarian industry. Born in Switzerland in 1814, Ganz operated an iron manufactory before establishing a workshop in 1844 in Hungary, the products of which became known throughout Europe (Hambuch 1998: 457). Born in 1834 in the German town of Schweinfurt, András Mechwart was an engineer and factory owner who moved to Hungary in 1859, at which time be began working in Ganz's iron foundry. After his death, Ganz's business was transformed into a joint stock company directed by Mechwart whose many inventions further enriched Hungarian industry, even earning him a noble rank in 1899 (Hambuch 1998: 457).

In the area of culture, the famous composers Ferenc Liszt (1811, Doborján, today Burgenland, Austria - Bayreuth, 1886) and Ferenc Erkel came from German origins. Known around the world for his compositions and interpretation of the piano, Liszt changed his name from List in 1859. Between 1851 and 1854 he composed the Hungarian Rhapsodies and premiered his Hungarian Coronation Mass in 1867 at Emperor Franz Jospeh's crowning held at Matthias Church in Buda (Hambuch 1998: 451). Perhaps less familiar internationally, Ferenc Erkel (1810, Gyula - 1893, Budapest) founded Hungarian national opera beyond composing the Hungarian National Anthem. With ancestors who originally came from Cologne, Erkel settled in Pest in1835-ben Pest, where he led the orchestra at the Municipal German Theater in Pest for two years before becoming the first conductor for the Hungarian Theater of Pest (later the National Theater of Hungary) in 1837. Erkel composed major operatic works in Hungarian, such as László Hunyadi and Bánk bán. In1875 he helped to found the Academy of Music which he then directed until 1885 (Hambuch 1998: 450-451). Naturally, the dramatic talents of actresses such as Lujza Blaha (born Reindl, Rimaszombat, 1850 - Budapet 1926) and Mari Jászai (born Krippel, Ászár, 1850 - Budapest 1926) also contributed greatly to the history of the National Theater of Hungary.

Other than music and theater, Hungarian culture would not be complete without the contribution of authors such as Géza Gárdonyi, born Géza Ziegler (Agárdpuszta, 1863 - Eger, 1922). One of the most important figures in nineteenth- and twentieth-century, Hungarian literature, Gárdonyi is most recognized for his historical novel, Egri csillagok [The Stars of Eger] (https://mnl.gov.hu/mnl/ol/hirek/hogy_lett_ziegler_gezabol_gardonyi_geza), an epic work depicting the siege of Eger castle during the Ottoman period that remains a firm part of Hungarian literature curricula for sixth-grade students. Originally born Sándor Großschmid (Kassa; Košice, 1900 - San Diego, 1989), the author Sándor Márai's ancestors were Zipsers, a group of Saxon Germans found in the Szepes region of Slovakia's Upper Highlands (https://hu.wikipedia.org/wiki/M\%C3\%A1rai_S\%C3\%A1ndor). Known for his prose, poetry and journalism, Márai was the first to translate Franz Kafka into Hungarian. In 1948, he emigrated to Switzerland before settling in the United States in 1952. In 1956, the outbreak of the Hungarian Revolution prompted him to return to Europe. In 1979, he moved back to the United States and lived in San Diego until his death (Hambuch, 1998: 421).

To continue our list, we would like to add the contributions of Ignác Fülöp Semmelweis (Buda, 1818 - Vienna, 1865), "the savior of mothers" who was a pioneer in inroducing antiseptic measures to medical procedures. Nor would Budapest's streets be the same without the talents of the architects, Mihály Pollack (1772, Vienna - 1855, Pest) and Miklós Ybl (Székesfehérvár, 1814 - Budapest, 1891). The world of Hungarian soccer owes much to Ferenc Puskás (born Purczeld, Budapest, 1927 - Budapest, 2006), captain of the famous "Golden Team" who, other than his famous nickname of Öcsi ['Kid Brother'], was also called Sváb ['Swabian'] due to his German roots. Last but not least, it is quite appropriate that this examination of education 
Márkus, Éva and Maya Lo Bello. "Mihály Lieb or Mihály Munkácsy? Developing Cultural Identity in Hungary’s German National Minority Schools." Hungarian Cultural Studies. e-Journal of the American Hungarian Educators Association, Volume 14 (2021): http://ahea.pitt.edu DOI: 10.5195/ahea.2021.426

conclude with the name of Hungary's most well-known educator, Teréz Brunszvik (born Brunswick, Pozsony, 1775 - Pest, 1861), the Hungarian countess of German ancestry who, in 1828, established Angyalkert ['Angel Garden'], the first preschool in the entire AustroHungarian Empire in Buda (Hambuch 1998: 423). For a continuation of famous individuals whose lives and accomplishments provide an endless source of pride in the combined history of Hungarians and Germans, see Hambuch (1998: 373-458) and Márkus (2008: 77, 80, 92, 105, 148-149).

By briefly examining the interwoven network of cultural, historical and economic ties that have connected German minorities to Hungarians, this paper has contended that the dual identity of Hungarian Germans can and should be preserved for the sake of following generations. Attaining this aim is best accomplished with the aid of Hungarian German minority schools, where national education standards mandate the subject of folk education. While attending a weekly class that allows students to explore their Hungarian German heritage is a positive step toward diminishing the discrimination and historical trauma that many Hungarian German families have endured, restoring the linguistic and cultural damage caused by advanced assimilation requires even greater efforts. Even as the topics recommended for folk education classes draw adequate attention to the differences between mainstream Hungarian history and the divergent historical processes experienced by Hungarian Germans, a close analysis of the curricular guidelines reveals that increased attention must be paid to instilling students with a deeper sense of pride and personal connection regarding their cultural heritage. We therefore urge educators to encourage students to explore the lives of the many, famous, individuals whose accomplishments owe much to the unique sense of Doppelidentität that defines Hungary's Germans.

\section{Works Cited}

A német nemzetiségi nevelés-oktatás kerettantervei ['Curricular Guidelines for German Minority Education']. https://www.oktatas.hu/kozneveles/kerettantervek/2020_nat/nemzetisegi_neveles_oktatas kerettantervei/nemet, 2020.

Echeverria, Begoña. 2003. "Schooling, Language, and Ethnic Identity in the Basque Autonomous Community." Anthropology \& Education Quarterly 34.4: 351-372.

Erb, M., et al. 2010. Gyökerek és szárnyak. A magyarországi németek nevelési, oktatási és közmüvelödési programja ['Roots and Wings: A Program for the Education and Instruction of Hungary's Germans']. Budapest.

EMMI rendelet a nemzetiség óvodai nevelésének irányelve és a nemzetiség iskolai oktatásának irányelve kiadásáról ['EMMI Order for Guidelines in National Ethnicity Preschool Primary School Education'], 2013. http://net.jogtar.hu/jr/gen/hjegy_doc.cgi?docid=A1300017. EMMI

Garadnai, Zoltán. 2013. Hogy lett Ziegler Gézából Gárdonyi Géza? ['How Did Géza Ziegler Become Géza Gárdonyi?'] Magyar Nemzeti Levéltár. https://mnl.gov.hu/mnl/ol/hirek/hogy_lett_ziegler_gezabol_gardonyi_geza

Hambuch, Vendel, editor. 1998. Németek Budapesten ['Germans in Budapest']. Budapest: Fővárosi Német Kisebbségi Önkormányzat.

Kerettantervek 2013 szeptembertöl ['Curricular Guidelines as of September, 2013']. http:// www.udpi.hu/hu/dokumentumok/kerettantervek/kerettantervek-2013-szeptembertol 
Márkus, Éva and Maya Lo Bello. "Mihály Lieb or Mihály Munkácsy? Developing Cultural Identity in Hungary’s German National Minority Schools." Hungarian Cultural Studies. e-Journal of the American Hungarian Educators Association, Volume 14 (2021): http://ahea.pitt.edu DOI: 10.5195/ahea.2021.426

Márkus, Éva. 2008. "Denn ein Reich mit einer Spache [...] ist hinfällig“. Ein Lehr-und Arbeitsbuch zur Geschichte der Deutschen in Ungarn. für die Studenten der Nationalitätengrundschullehrer- und - kindergärtnerInnenbildung." Nemzetiségismeret a magyarországi németek története. Oktatási segédanyag a nemzetiségi tanitó és óvodapedagógus hallgatók számára ['Ethnic Studies: The History of Hungarian Germans. Educational Materials for Primary and Preschool Educators in Minority Studies']. Budapest: Trezor Kiadó. http://mek.oszk.hu/08800/08817/08817.pdf

Márkus, Éva. 2014. “A német nyelvjárások szerepe a német nemzetiségi oktatásban” ['The Role of German Dialects in German Minority Education']. A korai idegen nyelvi fejlesztés elmélete és gyakorlata. Konferenciaelöadások és háttértanulmányok ['The Theory and Practice of Early Foreign Language Development: Conference Lectures and Studies'] Eds. Éva Márkus and Ėva Benkő Trentinné. Budapest: ELTE Eötvös Kiadó: 322-329. http://tamop2014.tok.elte.hu/dok/szakmai_anyagok/tp_modszertani_anyagok/Markus_Tr entinne_2014_A_korai_idegennyelvi_fejlesztes_elmelete_es_gyakorlata.pdf

Márkus, Éva. 2016. "A német nemzetiségi gyermekirodalom gyöngyszemei” ['Jewels of German Minority Children's Literature'] A gyermekkultúra jelen(töség)e ['Children's Culture and Its Significance'] Eds. Nedda Kolosai and Tibor M. Pintér. Budapest: Komáromi Nyomda: 164-173. http://gyermekkultura.tok.elte.hu/docs/Gyermekkultura_ebook.pdf

Márkus, Éva and Mira Gölcz. 2018. “A magyarországi német nemzetiség nyelvelsajátítási szokásai" ["Characteristics in the Language Acquisition of Hungarian Germans']. Gyermeknevelés 6. 3: 56-69. DOI: https://doi.org/10.31074/201835669. http://gyermekneveles.tok.elte.hu/18 3/gyn_2018-3_markus_golcz_56-69.pdf

Manherz, Károly. 1998. A magyarországi németek ['Hungarian Germans']. Budapest: Útmutató Kiadó.

Morcom, Lindsay A. and Stephanie Roy. 2017. "Learning Through Language: Academic Success in an Indigenous Language Immersion Kindergarten." Journal of American Indian Education 56.2: $57-80$.

Navracsics, Judit. 2004. A kétnyelvü gyermek ['The Bilingual Child']. Veszprém: Pannon Egyetemi Kiadó.

Seewann, Gerhard. 2013. A magyarországi németek történetének vázlatos áttekintése ['An Overview of the History of Hungarian Germans]. Hitel 26. 8: 84-92. http://epa.oszk.hu/01300/01343/00139/pdf/EPA01343 hitel_2013_08-084-092.pdf

------. 2012. Geschichte der Deutschen in Ungarn ['History of the Germans in Hungary']. Band 2: 1860 bis 2006. Marburg: Verlag Herder-Institut. https://digital.herderinstitut.de/publications/frontdoor/deliver/index/docId/105/file/Studien_24II_ISBN_978387 9693740.pdf

Slomanson, Peter. 2012. "On the Great Silence: A Gap in Irish Historiography and Consequences for Language Education in Ireland." Nordic Irish Studies 11.2: 95-114.

Steh dazu! A Magyarországi Németek Országos Önkormányzata stratégiája 2020 ['Stand For Your Rights! The Hungarian German National Municipality Council's Strategy Till 2020']. Budapest, 2016. http:// www.ldu.hu/page/391

Száray, Miklós. 2013. Történelem 10. A négyosztályos gimnáziumok és a szakközépiskolák számára ['History for Grade 10 in Four-Year Secondary and Vocational Schools']. EKE OFI.

Williams, Colin H. 2014. "The Lightening Veil: Language Revitalization in Wales.” Review of Research in Education 38: 242-272. 